\title{
Effect of microwave treatment on cooking time, colour, sensory and nutritional properties of Bambara groundnut (Vigna subterranea)
}

\author{
Samson A. Oyeyinka ${ }^{* 1,2}$, Aishat O. Ajisafe ${ }^{2}$, Olaide A. Akintayo ${ }^{2}$, Oluyinka A. Iyiola ${ }^{3}$, Adewumi T. Oyeyinka ${ }^{4}$, Sogo \\ J. Olatunde ${ }^{5}$, Abdul-Hameed A. Badmos ${ }^{6}$, Beatrice M. Fasogbon ${ }^{7}$, Nikita Patel ${ }^{8}$
}

\author{
${ }^{I}$ School of Agriculture and Food Technology, University of the South Pacific, Apia, Samoa \\ ${ }^{2}$ Department of Home Economics and Food Science, University of Ilorin, Ilorin, Nigeria \\ ${ }^{3}$ Department of Zoology, University of Ilorin, Ilorin, Nigeria \\ ${ }^{4}$ Department of Food Science and Technology, Kwara State University, Malete, Nigeria \\ ${ }^{5}$ Department of Food Science, Ladoke Akintola University of Technology, Ogbomoso, Nigeria \\ ${ }^{6}$ Department of Animal Production, University of Ilorin, Ilorin, Nigeria \\ ${ }^{7}$ Department of Food Technology, Federal Institute of Industrial Research, Oshodi, Nigeria \\ ${ }^{8}$ C.G. Bhakta Institute of Biotechnology, Uka Tarsadia University Gujarat, India
}

*Corresponding author: sartf2001@yahoo.com,oyeyinka.sa@unilorin.edu.ng

\begin{abstract}
Bambara groundnut is a leguminous crop that currently experiences a low level of utilisation because it is hard-to-cook and difficulty to dehull. In this study, the effects of different microwaving power of 450, 500, 600 and $750 \mathrm{~W}$ and time (0, 30, 60, 120 and $240 \mathrm{~s})$ on cooking time, colour, sensory and nutritional properties of Bambara groundnut using standard methods were investigated. Microwaving generally reduced the cooking time of Bambara groundnut. The cooking time reduced by approximately 28, 46, 52 and 55\% when Bambara groundnut was microwaved at 450, 500, 600 and $750 \mathrm{~W}$ for $240 \mathrm{~s}$, respectively. Microwaving did not significantly ( $p>0.05)$ affect the colour and appearance of the grain. Bambara groundnut had similar lightness values (60.66-63.15), but slightly different a (3.38-5.57) and b values (16.16-19.20) after microwaving. Protein (23.90-26.88\%) and carbohydrate (47.85-58.58\%) were the major components of raw and microwaved grains. Microwaved grains showed higher digestibility values (approx. 78-85\%) compared to the raw Bambara groundnut (approx. 71\%). Mean sensory scores revealed that Bambara groundnut microwaved at $600 \mathrm{~W}$ for $240 \mathrm{~s}$ had comparable acceptability with the control sample. Microwaving can be used to reduce cooking time of Bambara groundnut, improve protein content and digestibility without significantly altering the sensory properties.
\end{abstract}

Keywords: Vigna subterranea, in-vitro protein digestibility, microwave, cooking time

\section{Introduction}

Bambara groundnut is a leguminous crop with potential to address food and nutrition security in Africa, because of its high nutritional value. The grains are rich in carbohydrate (57-67\%) and proteins (15-27\%) (Arise, et al., 2015; Oyeyinka, et al., 2017; Oyeyinka, et al., 2015) with very low amounts of fat, usually less than 10\% (Oyeyinka and Oyeyinka, 2018). Furthermore, Bambara groundnut is reportedly richer in methionine compared to other commonly consumed legumes including soya bean and can be potentially used as a functional ingredient in the industry (Oyeyinka and Oyeyinka, 2018). However, the grain is underutilized due to the development of the hard-to-cook (HTC) defect during storage (Mubaiwa, et al., 2019). This defect is a common problem that has limited the utilization of many pulses and occurs at relatively high temperature $\left(30-40{ }^{\circ} \mathrm{C}\right)$ and relative humidity $(>75 \%)$ as commonly experienced in sub-Saharan Africa (Mubaiwa, et al., 2017). Besides storage conditions, seed size, ripening degree, and genetic factors may also contribute to HTC phenomenon in pulses (Bhatty, 1988; Liu and McWatters, 1994). Previous studies reported that HTC defect results in high energy and consequently reduces the nutritive value of the grain (Molina and Bressani, 1975; Paredes-López, et al., 1991). The HTC defect also affects the dehulling of grains (Mubaiwa, et al., 2017). For example, dehulling of black gram has been reported to be a very difficult operation due to the presence of vitreous layer of gums and mucilages, which makes bond between hull and cotyledon stronger (Joyner and Yadav, 2015). Earlier attempt to reduce cooking time of some legumes focused on the use of soaking solutions such as sodium chloride $(\mathrm{NaCl})$ (Huma, et al., 2008; Paredes-López, et al., 1991), water (Huma, et al., 2008), sodium hydrogen trioxocarbonate IV $\left(\mathrm{NaHCO}_{3}\right)$ (Paredes-López, et al., 1991) and sodium bicarbonate (Huma, et al., 2008). Huma, et al. (2008), reported approximately $37 \%$ reduction in cooking time when red kidney bean was soaked in water for $6 \mathrm{~h}$, while chick pea showed a higher reduction (44\%) when soaked for the same time. More recently, Mubaiwa, et al. (2019), reported the use of alkaline rock salts (gowa) and $\mathrm{NaHCO}_{3}$ in reducing the cooking time of Bambara groundnut. These authors found that $0.5 \mathrm{~g} / 100 \mathrm{~mL}$ gowa and $0.5 \mathrm{~g} / 100 \mathrm{~mL}$ NaHCO3 decreased cooking time of red Bambara groundnut by approximately $20 \%$ and $13 \%$, respectively, in comparison with cooking in deionised water. Although soaking in solutions may be important to soften grains and facilitate cooking, there are reports of nutrient losses due to leaching of water-soluble components of grains. For instance, chickpea and lentil grains soaked in $2 \%$ sodium chloride solution showed approximately 16 and $20 \%$ loss in protein content respectively (Huma, et al., 2008). Thus, promising methods such as microwave heating that would not require soaking prior to cooking are required to reduce nutrient losses associated with soaking. According to Joyner and Yadav (2015) microwave heating results in the disruption of bond between hull and cotyledon of pulses by denaturing the protein and gums present in between them. These authors found that microwaving of black gram at varying microwaving power and time resulted in significant reduction in cooking time. Furthermore, the microwaving treatment also facilitated the dehulling process. The dehulling time for black gram was reduced by $62.3 \%$ when compared to the control sample (Joyner and Yadav, 2015).

Bambara groundnut is becoming a crop of importance that may be explored for various nutrition interventions and for enhancing the nutritional value of traditional products. The effect of microwave 
treatment on cooking time and nutrient composition of Bambara groundnut has not been studied previously, but microwaving has been shown to improve protein digestibility (Alajaji and El-Adaw, 2006; Khatoon and Prakash, 2004, 2006; Negi, et al., 2001) and reduce antinutrients in legumes (Rajko, et al., 1997). Hence, this study investigates the effect of microwave heating power and time on colour, cooking time, sensory and nutritional properties of Bambara groundnut.

\section{Materials and methods}

Bambara groundnut with cream coat colour was obtained from a local market (Oja Oba) in Ilorin, Nigeria. The grains were sorted and kept in a refrigerator controlled at $4^{\circ} \mathrm{C}$ until the grains were needed for the experiment.

\section{Microwave treatment}

Microwaving of Bambara grains was done as previously described in the study of Joyner and Yadav (2015) with some slight modification. Briefly, Bambara groundnut was microwaved using a microwave (Model MEJ11K, LG, Kuala Lumpur, Malaysia) at varying power (450, $500,600$ and $750 \mathrm{~W})$ and time $(0,30,60,120$ and $240 \mathrm{~s})$ to determine the optimum microwaving time using $100 \mathrm{~g}$ of cleaned Bambara grains in a beaker. The moisture content of the grain was increased to $30 \%$ prior to microwaving by adding a calculated amount of water based on mass balance. Subsequent analyses were then carried out at varying microwaving power for $240 \mathrm{~s}$ (the maximum exposure time).

\section{Cooking time of grains using traditional method}

The conventional cooking method which involves boiling $\left(100{ }^{\circ} \mathrm{C}\right)$ the grains in water $(2 \mathrm{~L})$ at atmospheric pressure until the seeds were softened. Bambara grains were periodically checked for softness by pressing them between fingers and the thumb (Hernandez-Infante, et al., 1998).

\section{Colour Parameters}

The CIE tristimulus $L, a$, and $b$ parameters of the samples were measured using a chroma meter (A60-1014-593, Hunter Associates, Reston, VA, USA) as previously described (Oyeyinka, et al., 2018). L (lightness) axis -0 is black, 100 is white, $a$ (red-green) axis-positive values are red, negative values are green and 0 is neutral; $b$ (yellow-blue) axis- positive values are yellow, negative values are blue and 0 is neutral. Total colour difference $(\Delta \mathrm{E})$ were calculated according to equation given below (Falade and Oyeyinka, 2015).

$$
\Delta E=\sqrt{(\Delta L)^{2}+(\Delta a)^{2}+(\Delta b)^{2}}
$$

Where: $\Delta \mathrm{L}=$ Change in $\mathrm{L}$ calculated by subtracting the $\mathrm{L}$ values of microwaved samples from that of the control, $\Delta \mathrm{a}=$ change in a calculated by subtracting the a values of microwaved samples from the that of the control and $\Delta \mathrm{b}=$ change in $\mathrm{b}$ calculated by subtracting the $\mathrm{b}$ values of microwaved samples from the that of the control.

\section{Basic chemical composition of Bambara grains}

Moisture, fat, protein and ash contents were determined using standard methods described by AOAC (2000), while the carbohydrate was calculated by difference. Fibre contents were determined by digestion in sulfuric acid and sodium hydroxide (Kirk and Sawyer, 1991).

\section{In-vitro protein digestibility}

In-vitro protein digestibility of the samples was done as previously described (Hamaker, et al., 1987). Sample (0.2 g) was weighed, 35 $\mathrm{mL}$ of $0.1 \mathrm{M}$ phosphate buffer: $\mathrm{pH} \mathrm{2,} \mathrm{containing} 1.5 \mathrm{mg}$ pepsin/mL was added. Pepsin-sample mixture was incubated at $37^{\circ} \mathrm{C}$ for 2 hours with continuous shaking. Digestion was stopped by adding $2 \mathrm{~mL}$ of 2 $\mathrm{M} \mathrm{NaOH}$. The suspension was centrifuged at $4800 \mathrm{rpm}$ at $4{ }^{\circ} \mathrm{C}$ for 20 min and the supernatant was discarded. The residue was washed with 15 $\mathrm{mL}$ of $0.1 \mathrm{M}$ phosphate buffer: $\mathrm{pH} 7$ and centrifuged again as previously done, the supernatant was again discarded and the residue washed on Whatman's No 3. filter paper. The filter paper containing the undigested protein residue was folded and placed in a digestion tube and dried for 2 hours at $80{ }^{\circ} \mathrm{C}$. The dried sample was analysed for protein as described above.

\section{Sensory evaluation}

Sensory evaluation of the samples were carried out as described by Karim, et al. (2015). Briefly, a 9- point hedonic preference scale and a multiple comparison test were used to assess the acceptability of the samples. Thirty (30) semi-trained panellists, selected from student of the Department of Home Economics and Food Science, University of Ilorin, Nigeria were used for the evaluation. The selected students were those accustomed to eating Bambara groundnut. Prior to the sensory analysis, they were screened with respect to their interest and ability to differentiate food sensory properties. The samples were evaluated for appearance, aroma, taste, softness and overall acceptability.

\section{Statistical analysis}

Duplicate samples were prepared and all laboratory analyses were done in triplicate. Data was analysed using one-way analysis of variance (ANOVA) and means were compared using the Fisher Least Significant Difference (LSD) test $(\mathrm{p} \leq 0.05)$ using the Statistical Package for the Social Sciences (SPSS) Version 16.0 for Windows (SPSS Inc., Chicago, IL, USA).

\section{Results and discussion}

\section{Cooking time}

The cooking time (approx. 2h) of Bambara groundnut significantly $(\mathrm{p}<0.05)$ reduced with increasing microwaving time (Figure 1). At shorter microwaving time $(\leq 120 \mathrm{~s})$, there was no particular trend on the effect of microwaving power on the cooking time. Longer microwaving time $(>120 \mathrm{~s})$ showed distinct effect of microwaving power, with cooking time reducing with increasing microwaving power (Figure 1). Cooking time reduced by approximately 28, 46, 52 and $55 \%$ when Bambara groundnut was microwaved at 450, 500, 600 and 750 $\mathrm{W}$ for $240 \mathrm{~s}$, respectively. The reduction in cooking time presumably results from increase in intermolecular space between the hull and the cotyledon due to the energy released during microwaving, which allows ease of water absorption during cooking (Joyner and Yadav, 2015). The reduction in cooking time of microwaved Bambara groundnut may also be associated with possible fissures or weakening of the seed coat during microwaving. Earlier researchers found by scanning electron microscope that microwaving resulted in fractures in chickpea and mung bean, which was associated with puffing action caused by moisture pressure build-up (Divekar, et al., 2017). These authors also reported alteration in starch granules in the cotyledon as cavities were observed resulting from starch gelatinisation. These changes may have contributed to increased water absorption during cooking, resulting in reduced cooking time. Ogundele and Emmambux (2018) reported greater reduction in cooking time after infrared treatment of whole (49-62\%) and dehulled (75-80\%) Bambara groundnut for 5,10 and 15 mins. The slightly higher reduction in cooking 
time of infrared treated Bambara groundnut compared with the values recorded in this study could be attributed to several factors. Firstly, infrared heating has a higher penetrating power than microwave due to their respective positions in the electromagnetic spectrum. Secondly, the infrared heating time (5, 10 and 15 mins) used in the infrared study is higher than the microwave heating time $(30,60,120$ and $240 \mathrm{~s})$ in the current study. The dehulling process as well as pre-soaking of the grains as reported by Ogundele and Emmambux (2018), which facilitated hydration of the grains may also explain the variation in cooking time.

\section{Colour}

After establishing the maximum time of $240 \mathrm{~s}$ as the time corresponding to the beginning of the emergence of roasted smell, further analyses were done at this time and varying microwaving power. Colour of the grains were generally not altered by microwaving (Table 1). Lightness (L) value, although reduced slightly with increase in microwaving power, the reduction was not significant ( $\mathrm{p} \geq 0.05$ ) (Table 1). The $a$ and $b$ values were positive and both increased with increasing microwaving time. The total colour difference $(\Delta \mathrm{E})$ increased with increasing microwaving power, but the increase beyond $500 \mathrm{~W}$ was not significant $(\mathrm{p} \geq 0.05)$ (Table 1). The lowest $\Delta \mathrm{E}$ value (1.94) was recorded for Bambara groundnut microwaved at $450 \mathrm{~W}$ for $240 \mathrm{~s}$, while the highest was recorded for sample microwaved at $750 \mathrm{~W}$ for the same time. Joyner and Yadav (2015), similarly reported increase in $\Delta \mathrm{E}$ with increasing microwaving power for black gram (Vigna mungo L).

\section{Basic chemical composition of Bambara grains}

Microwaving significantly affected the composition of Bambara groundnut (Table 2). Protein (23.90-26.88\%) and carbohydrate (47.85$58.58 \%$ ) were the major components of raw and microwaved grains. The protein and fibre contents of the grains increased slightly with increase in microwaving power, while microwaving had different effect on other nutrients. Increase in protein content following various thermal treatments have been previously observed in different legumes (Ekpenyong and Borchers, 1980; Wang, et al., 2009). Microwaving of Bambara groundnut at $450 \mathrm{~W}$ for $240 \mathrm{~s}$ had no significant effect on the protein content. However, a slight but significant increase (approx. $4-11 \%$ ) in protein content was observed at higher microwaving power (500-750 W). Ekpenyong and Borchers (1980), found that the protein content of winged beans (Psophocarpus tetragonolobus) increased by $14 \%$ after cooking. According to these authors, the increase in protein was due to loss of soluble solids during soaking and cooking. In this study, the composition of the grains was determined after microwaving prior to cooking to establish the impact of microwaving on the nutrients. Since the grains were not soaked and were only hydrated prior to microwaving, it is not likely that protein increase resulted from loss of soluble solids. It is hypothesized that the increase in protein was due to destruction of anti-nutrients such as tannins in the grains which led to a concomitant increase in the assayed protein. Tannins form complexes with proteins through hydrogen bonding, hydrophobic, ionic, and covalent reactions (Hagerman, 1992). However, the complexes formed between tannin and protein can be dissociated by mild treatments. Furthermore, microwaving may also have resulted in protein denaturation and starch gelatinisation which in turn may increase bioavailability of inherent nutrients as previously reported (Palermo, et al., 2013).

Ash (1.97-2.34\%), fibre (2.31-2.81\%) and fat contents (5.19-5.69\%) were generally low. Pulses such as Bambara groundnut have relatively low fat content $(<10 \%)$ when compared with oil seeds such as soybean and peanuts (Oyeyinka and Oyeyinka, 2018). Microwaved Bambara groundnut showed significantly $(\mathrm{p}<0.05)$ higher moisture contents (10.01-18.60\%) compared with the control samples $(7.36 \%)$, which is due to the hydration done prior to microwaving. Thus, microwaved Bambara grains must be dried to safe moisture levels $(<10 \%)$, if the grains will not be consumed immediately after microwaving.

\section{In-vitro protein digestibility}

The in-vitro protein digestibility (IVPD) of raw Bambara groundnut was significantly improved after microwaving (Figure 2). Microwaved grains showed higher IVPD values (approx. 78-85\%) compared to the raw Bambara groundnut (approx. 71\%). Earlier studies on IVPD of raw Bambara groundnut reported $78.75 \%$ (Yagoub and Abdalla, 2007), while in-vivo (true) digestibility of Bambara groundnut using animals reported $77.01 \%$ (Nwokolo, 1987). Low protein digestibility of legumes has been associated with the presence of anti-nutritional factors such as trypsin inhibitors, polyphenols and phytic acid (Jood, et al., 1998). Thus, the improvement in protein digestibility may be attributed to denaturation of protein and destruction of anti-nutritional factors (Alajaji and El-Adaw, 2006). Previous studies similarly reported improvement in protein digestibility following microwaving of different legumes (Alajaji and El-Adaw, 2006; Khatoon and Prakash, 2004, 2006; Negi, et al., 2001). Furthermore, increased IVPD could also be due to the partial breakdown of storage proteins into more simple and soluble products (Mohiedeen, et al., 2010). In addition microwave heating reportedly changed the protein secondary structures in legumes (Divekar, et al., 2017). These changes may explain the slight increase in the protein content of Bambara groundnut after microwaving (Table 2) and the greater reduction in cooking time (Figure 1) of microwaved samples.

\section{Sensory evaluation}

Mean sensory scores of the microwaved grains are shown in Table 3. Microwaving had slight effect on the sensory properties of Bambara groundnut. Microwaved Bambara groundnut had lower ratings for softness, appearance and overall acceptability compared with the control sample, which was not microwaved. However, the effect of microwave on aroma and appearance of the grains were not significant confirming the objective colour measurement result (Table 1). Bambara groundnut microwaved at $600 \mathrm{~W}$ for $240 \mathrm{~s}$ had the highest rating in aroma and taste compared to the control and other microwaved samples. Furthermore, this sample had comparable overall acceptability ratings with the control.

\section{Conclusions}

Microwave treatment is a promising technology for reducing the cooking time of Bambara groundnut without substantially altering the colour, sensory properties and protein content of the grains. Bambara groundnut may be microwaved prior to cooking for improvement in protein content and digestibility. This study has further demonstrated the possibility of improving the utilisation of the grain at both urban and rural centres. Future studies may be required to determine the impact of microwaving on the amino acid composition of the microwaved grains.

Authors have no conflict of interest. 
Table 1. Colour of raw and microwaved Bambara groundnut for $240 \mathrm{~s}$

\begin{tabular}{ccccc}
\hline Microwaving power (W) & $\mathrm{L}$ & $\mathrm{a}$ & $\mathrm{b}$ & $\Delta \mathrm{E}$ \\
\hline 0 & $63.15^{\mathrm{a}} \pm 1.76$ & $3.38^{\mathrm{b}} \pm 0.78$ & $16.16^{\mathrm{b}} \pm 1.10$ & - \\
450 & $62.95^{\mathrm{a}} \pm 3.97$ & $3.60^{\mathrm{b}} \pm 0.69$ & $16.50^{\mathrm{b}} \pm 1.52$ & $1.94^{\mathrm{b}} \pm 1.13$ \\
500 & $62.68^{\mathrm{a}} \pm 1.95$ & $4.50^{\mathrm{a}} \pm 1.15$ & $18.40^{\mathrm{a}} \pm 0.66$ & $3.52^{\mathrm{ab}} \pm 1.48$ \\
600 & $62.28^{\mathrm{a}} \pm 2.52$ & $4.54^{\mathrm{ab}} \pm 1.11$ & $18.30^{\mathrm{a}} \pm 1.72$ & $4.22^{\mathrm{a}} \pm 1.86$ \\
750 & $60.66^{\mathrm{a}} \pm 1.76$ & $5.57^{\mathrm{a}} \pm 0.96$ & $19.20^{\mathrm{a}} \pm 0.91$ & $4.45^{\mathrm{a}} \pm 1.74$ \\
\hline
\end{tabular}

Mean \pm S.D. Means with different superscript within the same column are significantly $(p<0.05)$ different. $\Delta E=$ Total colour difference

Table 2. Proximate composition of raw and microwaved Bambara groundnut (\%)

\begin{tabular}{ccccccc}
\hline Microwaving power (W) & Moisture & Protein & Fat & Ash & Fibre & Carbohydrate \\
\hline 0 & $7.36^{\mathrm{d}} \pm 0.01$ & $24.23^{\mathrm{c}} \pm 0.40$ & $5.19^{\mathrm{c}} \pm 0.11$ & $2.34^{\mathrm{a}} \pm 0.01$ & $2.31^{\mathrm{d}} \pm 0.01$ & $58.58^{\mathrm{a}} \pm 0.42$ \\
450 & $18.60^{\mathrm{a}} \pm 0.14$ & $23.90^{\mathrm{c}} \pm 0.48$ & $5.21^{\mathrm{c}} \pm 0.01$ & $2.09^{\mathrm{b}} \pm 0.01$ & $2.36^{\mathrm{c}} \pm 0.03$ & $47.85^{\mathrm{e}} \pm 0.59$ \\
500 & $15.01^{\mathrm{b}} \pm 0.01$ & $25.18^{\mathrm{b}} \pm 0.08$ & $5.50^{\mathrm{b}} \pm 0.01$ & $2.09^{\mathrm{b}} \pm 0.01$ & $2.79^{\mathrm{a}} \pm 0.01$ & $49.43^{\mathrm{d}} \pm 0.08$ \\
600 & $12.40^{\mathrm{c}} \pm 0.14$ & $26.18^{\mathrm{a}} \pm 0.08$ & $5.69^{\mathrm{a}} \pm 0.12$ & $2.01^{\mathrm{c}} \pm 0.01$ & $2.64^{\mathrm{b}} \pm 0.02$ & $51.09^{\mathrm{c}} \pm 0.19$ \\
750 & $10.01^{\mathrm{e}} \pm 0.01$ & $26.88^{\mathrm{a}} \pm 0.08$ & $5.22^{\mathrm{c}} \pm 0.01$ & $1.97^{\mathrm{d}} \pm 0.01$ & $2.81^{\mathrm{a}} \pm 0.01$ & $53.12^{\mathrm{b}} \pm 0.08$ \\
\hline
\end{tabular}

Mean \pm S.D. Means with different superscript within the same column are significantly $(p<0.05)$

Table 3. Mean sensory scores for cooked Bambara groundnut

\begin{tabular}{cccccc}
\hline Microwaving power $(W)$ & Softness & Aroma & Taste & Appearance & Overall acceptability \\
\hline 0 & $7.32^{\mathrm{a}} \pm 0.98$ & $6.48^{\mathrm{ab}} \pm 1.30$ & $7.08^{\mathrm{ab}} \pm 1.04$ & $7.20^{\mathrm{a}} \pm 1.04$ & $7.40^{\mathrm{a}} \pm 0.82$ \\
450 & $7.12^{\mathrm{a}} \pm 1.24$ & $6.04^{\mathrm{b}} \pm 1.27$ & $6.44^{\mathrm{b}} \pm 1.26$ & $6.84^{\mathrm{a}} \pm 1.14$ & $6.68^{\mathrm{b}} \pm 0.95$ \\
500 & $6.24^{\mathrm{c}} \pm 1.51$ & $6.24^{\mathrm{a} b} \pm 1.17$ & $6.72^{\mathrm{ab}} \pm 1.14$ & $6.68^{\mathrm{a}} \pm 1.15$ & $6.52^{\mathrm{b}} \pm 0.77$ \\
600 & $6.76^{\mathrm{abc}} \pm 1.51$ & $6.80^{\mathrm{a}} \pm 1.23$ & $7.28^{\mathrm{a}} \pm 1.24$ & $6.64^{\mathrm{a}} \pm 1.38$ & $6.92^{\mathrm{ab}} \pm 1.07$ \\
750 & $6.36^{\mathrm{bc}} \pm 1.60$ & $6.68^{\mathrm{ab}} \pm 0.99$ & $6.84^{\mathrm{ab}} \pm 1.28$ & $6.72^{\mathrm{a}} \pm 1.24$ & $6.80^{\mathrm{b}} \pm 1.00$ \\
\hline
\end{tabular}

Mean \pm S.D. Means with different superscript within the same column are significantly $(p<0.05)$

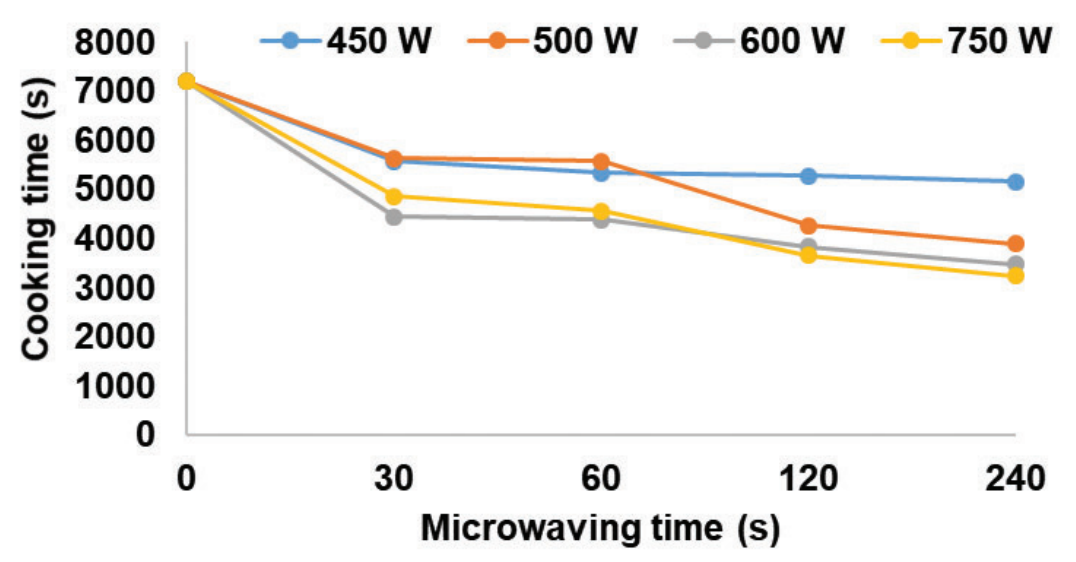

Figure 1. Effect of microwaving power and time on cooking time of Bambara groundnut 


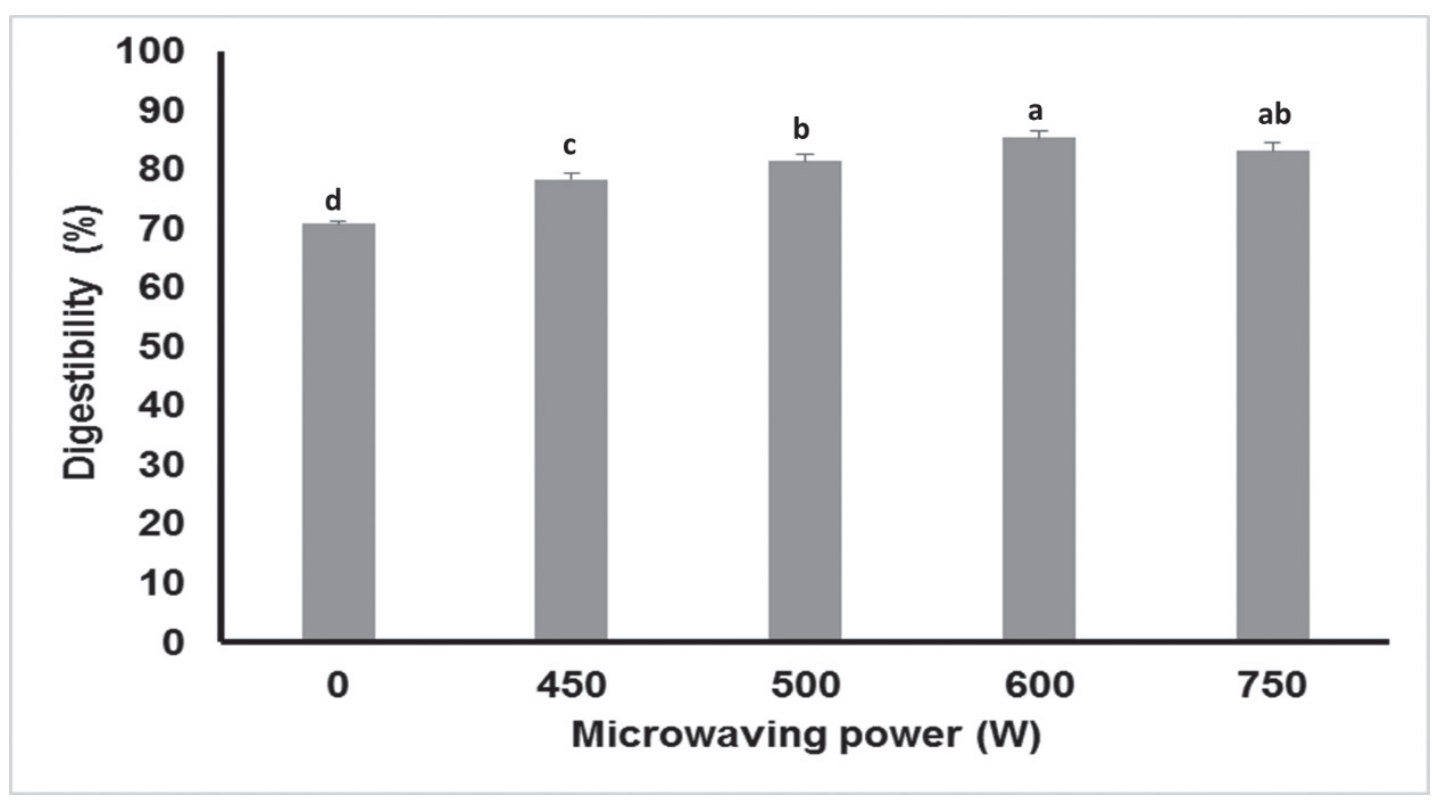

Figure 2. In-vitro protein digestibility of Bambara groundnut microwaved for $240 \mathrm{~s}$

Error bars indicate standard deviation $(N=3)$

\section{References}

Alajaji, S. A., El-Adaw, T. A. (2006) Nutritional composition of chickpea (Cicer arietinum L.) as affected by microwave cooking and other traditional cooking methods. Journal of Food Composition and Analysis, 19 (8) 806-812.

AOAC. (2000) Offcial methods of analysis. 17th edition. In: Asscoaition of official Analytical Chemists, Rockville.

Arise, A. K., Amonsou, E. O., Ijabadeniyi, O. A. (2015) Influence of extraction methods on functional properties of protein concentrates prepared from South African bambara groundnut landraces. International Journal of Food Science and Technology, 50 (5) 1095-1101.

Bhatty, R. S. (1988) Compostion and quality of lentils (lens culinaris). Canadian Institute of food Science and Technology jornal, 21 144-160.

Divekar, M. T., Karunakaran, C., Lahlali, R., Kumar, S., Chelladurai, V., Liu, X., Borondics, F., Shanmugasundaram, S., Jayas, D. S. (2017) Effect of microwave treatment on the cooking and macronutrient qualities of pulses. International Journal of Food Properties, 20 (2) 409-422.

Ekpenyong, T., Borchers, R. (1980) Effect of cooking on the chemical composition of winged beans (Psophocarpus tetragonolobus). Journal of Food Science, 45 (6) 1559-1560.

Falade, K. O., Oyeyinka, S. A. (2015) Color, Chemical and Functional Properties of Plantain Cultivars and Cooking Banana Flour as Affected by Drying Method and Maturity. Journal of Food Processing and Preservation, 39 (6) 816-828.

Hagerman, A. E. (1992). Tannin-protein interactions In Phenolic Compounds in Food and Their Effects on Health I (Vol. 506). ACS Symposium Series; American Chemical Society: Washington, DC.

Hamaker, B., Kirleis, A., Butler, L., Axtell, J., Mertz, E. (1987) Improving the in vitro protein digestibility of sorghum with reducing agents. Proceedings of the National Academy of Sciences, 84 (3) 626-628.

Hernandez-Infante, M., Sousa, V., Montalvo, I., Tena, E. (1998) Impact of microwave heating on hemagglutinins, trypsin inhibitors and protein quality of selected legume seeds. Plant Foods for Human Nutrition, 52 (3) 199-208.

Huma, N., Anjum, M., Sehar, S., Issa Khan, M., Hussain, S. (2008) Effect of soaking and cooking on nutritional quality and safety of legumes. Nutrition \& Food Science, 38 (6) 570-577.

Jood, S., Bishnoi, S., Sehgal, S. (1998) Effect of processing on nutritional and antinutritional factors of moongbean cultivars. Journal of Food Biochemistry, 22 245-257.

Joyner, J. J., Yadav, B. (2015) Microwave assisted dehulling of black gram (Vigna mungo L). Journal of Food Science and Technology, 52 (4) 20032012.

Karim, O., Kayode, R., Oyeyinka, S., Oyeyinka, A. (2015) Physicochemical properties of stiff dough 'amala' prepared from plantain (Musa Paradisca) flour and Moringa (Moringa oleifera) leaf powder. Food in Health and Disease, 4 (1) 48-58.

Khatoon, N., Prakash, J. (2004) Nutritional quality of microwave-cooked and pressure-cooked legumes. International Journal of Food Sciences and Nutrition, 55 (6) 441-448.

Khatoon, N., Prakash, J. (2006) Nutrient retention in microwave cooked germinated legumes. Food Chemistry, 97 (1) 115-112.

Kirk, S., Sawyer, R. (1991) Pearson's composition and analysis of foods, England Longman scientific and technical: Longman Group Ltd.

Liu, K., McWatters, K. H. (1994) Effects of storage, soaking and cooking method on cook ability of cowpeas. LWT- Food Science and Technology, 27 95-97.

Mohiedeen, I. E., El Tinay, A. H., Elkhalifa, A. E. O., Babiker, E. E., Mallasy, L. (2010) Effect of fermentation and cooking on protein quality of maize (Zea mays L.) cultivars. International Journal of Food Science \& Technology, 45 (6) 1284-1290. 
Molina, M., Bressani, R. (1975) Interrelationships between storage, soaking time, cooking time, nutritive value and other characteristics of the black bean (Phaseolus vulgaris). Journal of Food Science, 40 (3) 587-591.

Mubaiwa, J., Fogliano, V., Chidewe, C., Linnemann, A. R. (2017) Hard-to-cook phenomenon in bambara groundnut (Vigna subterranea (L.) Verdc.) processing: Options to improve its role in providing food security. Food Reviews International, 33 (2) 167-194.

Mubaiwa, J., Fogliano, V., Chidewe, C., Linnemann, A. R. (2019) Influence of alkaline salt cooking on solubilisation of phenolic compounds of bambara groundnut (Vigna subterranea (L.) Verdc.) in relation to cooking time reduction. LWT-Food Science and Technology, 107 49-55.

Negi, A., Boora, P., Khetarpaul, N. (2001) Effect of microwave cooking on the starch and protein digestibility of some newly released moth bean (Phaseolus aconitifolius Jacq.) cultivars. Journal of Food Composition and Analysis, 14 (5) 541-546.

Nwokolo, E. (1987) A nutritional assessment of African yam bean (Sphenostylis stenocarpa) H. and Bambara Groundnut (Voandzeia subterranea L.). Journal of the Science of Food and Agriculture, 41, 123-129.

Ogundele, O. M., Emmambux, M. N. (2018) Effect of infrared heating of pre-soaked whole and dehulled bambara groundnut (Vigna subterranea) seeds on their cooking characteristics and microstructure. LWT-Food Science and Technology, 97 581-587.

Oyeyinka, A. T., Pillay, K., Tesfay, S., Siweal, M. (2017) Physical, nutritional and antioxidant properties of Zimbabwean Bambara groundnut and effects of processing methods on their chemical properties International Journal of Food Science and Technology, 52 (10) $2238-2247$.

Oyeyinka, S. A., Oyeyinka, A. T. (2018) A review on isolation, composition, physicochemical properties and modification of Bambara groundnut starch. Food Hydrocolloids, 75 62-71.

Oyeyinka, S. A., Singh, S., Adebola, P. O., Gerrano, A. S., Amonsou, E. O. (2015) Physicochemical properties of starches with variable amylose contents extracted from bambara groundnut genotypes. Carbohydrate Polymers, 133 171-178.

Oyeyinka, S. A., Tijani, T. S., Oyeyinka, A. T., Arise, A. K., Balogun, M. A., Kolawole, F. L., Obalowu, M. A., Joseph, J. K. (2018) Value added snacks produced from Bambara groundnut (Vigna subterranea) paste or flour. LWT-Food Science and Technology, 88 126-131.

Palermo, M., Pellegrini, N., Fogliano, V. (2013) The effect of cooking on the phytochemical content of vegetables. Journal of the Science of Food and Agriculture, 94 (6) 1057-1070.

Paredes-López, O., Cárabez-Trejo, A., Palma-Tirado, L., Reyes-Moreno, C. (1991) Influence of hardening procedure and soaking solution on cooking quality of common beans. Plant Foods for Human Nutrition, 41 (2) 155-164.

Rajko, R., Szabo, G., Vidal-Valverde, C. E. K. (1997) Designed experiments for reducing antinutritive agents in soybean by microwave energy. Journal of Agricultural and Food Chemistry, 45 3565-3569.

Wang, N., Hatcher, D., Toews, R., Gawalko, E. (2009) Influence of cooking and dehulling on nutritional composition of several varieties of lentils (Lens culinaris). LWT-Food Science and Technology, 42 (4) 842-848.

Yagoub, A. A., Abdalla, A. A. (2007) Effect of domestic processing methods on chemical composition, in-vitro digestibility of protein and starch and functional properties of Bambara Groundnut (Voandzeia subterranea) Seed. Research Journal of Agriculture and Biological Sciences, 3 (1) 24-34. 